\title{
Cell wall functional activity and metal accumulation of halophytic plant species Plantago maritima and Triglochin maritima on the White Sea littoral zone (NW Russia)
}

\author{
Elena N. Terebova ${ }^{1}$, Evgenya F. Markovskaya ${ }^{1}$, Vera I. Androsova ${ }^{1}$, \\ Maria A. Pavlova ${ }^{1}$, Natalia V. Oreshnikova ${ }^{2}$ \\ ${ }^{1}$ Petrozavodsk State University, Department of Botany and Plant Physiology, Lenin st, \\ 33, Petrozavodsk 185910, Russian Federation \\ ${ }^{2}$ Lomonosov Moscow State University, GSP-1, Leninskie Gory, Moscow 119991, \\ Russian Federation
}

\begin{abstract}
The presented study supplements the knowledge on ion-exchange capacity, swelling capacity (elasticity) of the plant cell wall, and the accumulation of heavy metals in halophytic species Plantago maritima and Triglochin maritima in the tidal zone of the White Sea western coast. The littoral soils of the coastal territories are sandy or rocky-sandy, medium and slightly saline with poor content of organic substances, $\mathrm{Mn}, \mathrm{Zn}, \mathrm{Ni}$, and $\mathrm{Pb}$. Studied soils are considered as uncontaminated by heavy metals because they contain background amounts of $\mathrm{Fe}$ and $\mathrm{Cu}$. Sea water is significantly polluted by $\mathrm{Fe}$ (3.8 MPC) and $\mathrm{Ni}$ (55 MPC), has poor content of $\mathrm{Zn}$ and $\mathrm{Cu}$ and background level of $\mathrm{Pb}$ and $\mathrm{Mn}$. The coastal dominant plant species $P$. maritima and T. maritima were characterized by intensive metals accumulation which was reflected in the coefficient of biological absorption (CBA) of metal by a whole plant. For P. maritima the following metal accumulation series was obtained: $\mathrm{Cu}(3.29)>\mathrm{Zn}(2.81)>\mathrm{Ni}(1.57)>\mathrm{Pb}(1.30)>\mathrm{Mn}(1.21)>\mathrm{Fe}$ (0.97), and for T. maritima: $\mathrm{Ni}(3.80)>\mathrm{Fe}(2.08)>\mathrm{Cu}(1.91)>\mathrm{Zn}(1.84)>\mathrm{Pb}(1.51)>\mathrm{Mn}$ (1.31). Roots accumulated $50-70 \%$ of $\mathrm{Ni}, \mathrm{Cu}, \mathrm{Zn}, \mathrm{Pb}$ and $\mathrm{Mn}$ of the total metal content in the plant while leaves and stems contained $30-50 \%$. Fe was allocated mainly in the roots $(80 \%)$. The ion-exchange capacity of the plant cell wall for P. maritima and T. maritima was established as follows correspondingly: 3570-3700 and 2710-3070 $\mu \mathrm{mol} \mathrm{\textrm {g } ^ { - 1 }}$ dry cell weight per leaf; $2310-2350$ and $1160-1250 \mu \mathrm{mol} \mathrm{g}^{-1}$ dry cell weight per root.
\end{abstract}

Key words: plant cell wall, ion exchange capacity, swelling coefficient, heavy metals, coefficient of biological absorption, halophytes, estuary

DOI: $10.5817 / \mathrm{CPR} 2020-2-14$

Received June 25, 2020, accepted November 19, 2020.

*Corresponding author: E. Terebova <eterebova@gmail.com>

Acknowledgements: We are grateful to reviewers for valuable corrections and recommendations, which have improved the quality of our work. The research was carried out within the state assignment of Ministry of Science and Higher Education of the Russian Federation (theme No. 0752-2020-0007). 
List of abbreviations: ROS - reactive oxygen species, SP - sample plot, CBA - coefficient of biological absorption, $\mathrm{pKa}$ - ionization constants, $\mathrm{S}$ - sorption capacity, $\mathrm{K}_{\mathrm{cw}}$ - swelling coefficient, $\mathrm{COOH}$ PGUC - carboxyl group of $\alpha$-D-polygalacturonic acid, $\mathrm{COOH}$ HCA - carboxyl group of hydroxycinnamic acids, CAT - catalase, POX - peroxidase, SOD - superoxide dismutase, ABA - abscisic acid, Gs - stomatal conductance

\section{Introduction}

It is apparent that the cell wall is not only a physical barrier between the plant cell and the environment but also a very flexible and responsive part of the cell, functionally involved in growth and differentiation, signaling and response to pathogenic attack, and different stresses (Zagorchev et al. 2014). Cell wall proteins involved in stress signaling, in detoxification and ROS scavenging chaperones as well as proteins take also a part in cell wall modifications, for example enzymes of phenylpropanoid biosynthetic pathway and methyltransferases included in methylation of lignin components (Pandey et al. 2010). It is known that cell wall characteristics are associated with carbohydrate metabolism and secondary metabolism (Kosova et al. 2018).

In some studies devoted to acid-base properties of cell walls in herbaceous plants (Meychik et al. 1999), the cell walls were considered as weakly basic cation exchangers with a low crosslinking degree. Intracellular mechanisms of resistance include metal detoxification mechanisms (e.g. Hall 2002, Yadav 2010) such as production of phytochelatins and metallothioneins (Parrotta et al. 2015). Plant cell walls are rich in compounds, which are able to bind divalent and trivalent metal as well as salt cations. Polysaccharides play a crucial role in heavy metals binding and accumulation in the cell wall, although other compounds, such as proteins, amino acids and phenolics, also take part in this process. The ability to bind divalent metal cations depends on the number of functional groups, such as $-\mathrm{COOH},-\mathrm{OH},-\mathrm{NH}_{2}$, and $-\mathrm{SH}$, occurring in cell wall compounds
(Davis et al. 2003, Pelloux et al. 2007, Meychik 2007, Richter et al. 2017). According to Gorshkova (2007), the number of functional groups is species-specific and depends on the species origin, properties of the cell wall structure, physiological features as well as geographical range. It has been reported that the number of ionogenic groups in the structure of the plant cell wall of different organs can be affected by heavy metals (Krzeslowska 2011) and salinization (Meychik et al. 2006, 2010; Aguino et al. 2011). In previous studies, the high values of the ionexchange capacity and swelling coefficient were registered for leaf cell wall of arctic plants. It was connected to greater water flow system by the apoplast and enhance of the metabolic processes in the cell wall of plants at high latitudes (Terebova et al. 2018).

Sea coasts represent a contact zone between terrestrial and marine ecosystems (Markovskaya and Gulyaeva 2020). These areas are considered as the most unstable, because twice daily due to the diurnal rhythm of tidal cycles, they are exposed to changing of the water and air environments, accompanied by variations in climatic parameters: light intensity, temperature, oxygen and carbon dioxide concentrations, pressure and other factors (Bowes et al. 2002, Maberly and Madsen 2002, Kosobryukhov and Markovskaya 2016). In our study, we focused on the littoral of the White Sea, which is an estuarine territory of the Karelian rivers. Estuaries are flooded simultaneously by fresh water from large rivers that carry nutrient-rich sewage 
(Ilyin et al. 2015, [2]-State report 2018) and by salty sea water that move from the northern seas along the Karelian coastal territories through the White Sea. In fact, estuaries are complex systems which are governed by hydrographical factors, such as the tidal action and the mixing of freshwater and seawater, which produce complicated structural patterns that undergo continuous change in space and time (Kausch 1990). Moreover, estuaries are characterized by the unique combination of physical, chemical and biological features, and are distinguished by exceptionally high productivity (Alimov 2007, Telesh and Khlebovich 2010).

The aim of this study was to evaluate the ion-exchange capacity and swelling coefficient of leaf and root cell walls as well as metal accumulation of halophytic plant species Plantago maritima L. and Triglochin maritima L.

\section{Study area}

The work was carried out in July 2018 on the western coast of the White Sea from Lebyazhya Bay to Keretskaya Bay, which is the estuary of the Keret River (Fig. 1). Three sample plots (SP) of $5 \times 5 \mathrm{~m}$ were established on the tidal zone.

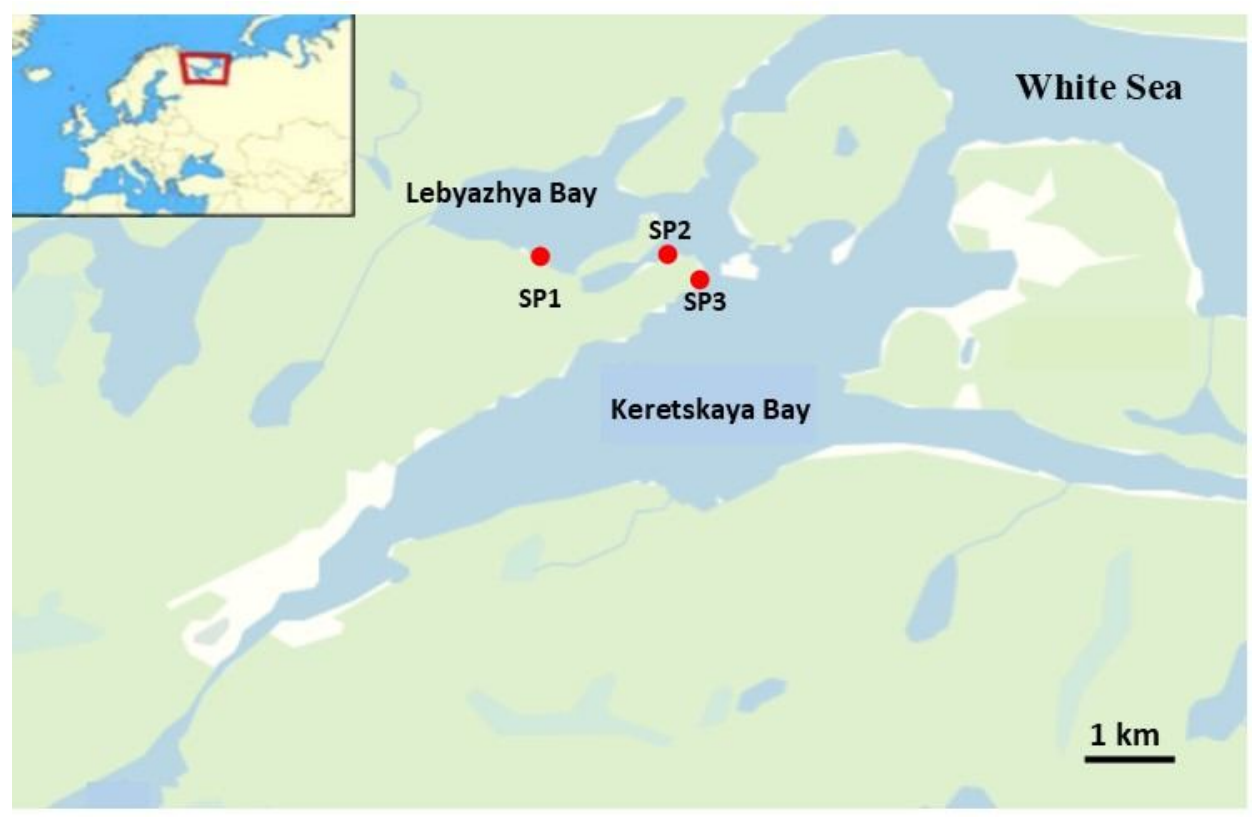

Fig.1. Locality of sample plots

SP 1 - the Lebyazhya Bay $\left(66^{\circ} 17^{\prime} 34.8^{\prime \prime} \mathrm{N}, 33^{\circ} 35^{\prime} 32.4^{\prime \prime} \mathrm{E}\right)$ is characterized by a sandystony series characteristic of steep littoral zones unprotected from the wave breakage. The coastal strip formed by the tidal wave is raised stepwise or gently above the littoral, a pebble sandy-clay substrate is characteristic, the ratio of pebbles: sand: clay is 235/160/105 (Breslina 1980); 
SP 2 - the exit from the Lebyazhya Bay $\left(66^{\circ} 17^{\prime} 34.8^{\prime \prime} \mathrm{N}, 33^{\circ} 36^{\prime} 30.4^{\prime \prime} \mathrm{E}\right)$, is characterized by sandy loam range characteristic of vast gentle sloping littoral zones, sufficiently protected from the wave breakdown of the lips, a clay-sandy substrate with an insignificant fraction of pebbles - 31/220/239;

SP 3 - the entrance to the Keretskaya Bay $\left(66^{\circ} 17^{\prime} 26.9^{\prime \prime} \mathrm{N}, 33^{\circ} 36^{\prime} 35.3^{\prime \prime} \mathrm{E}\right)$ is characterized by the littoral sandy soil or rocky-sandy, slightly silted $-85 / 345 / 70$. According to the geobotanical classification, the studied territories belong to low-level meadows (Oreshnikova et al. 2012).

\section{Material and Methods}

\section{Plant material}

Two species of halophytes, widely distributed on the White Sea coast, were chosen for the study: Triglochin maritima L. (Juncaginaceae) and Plantago maritima L. (Plantaginaceae).

Plantago maritima - euhalophyte, a Eurasian hypoarctic species (Fig. 2); herbaceous polycarpic perennial plant with monopodial rhizome and branched particulating caudex which prefers drying sites protected from wave erosion (Veselkin et al. 2016). It forms basal rosette of large leaves which are fleshy, narrow-lanceolate, covered with a layer of cuticle. Leaf mesophyll is isopalisade, slightly differentiated into palisade and spongy mesophyll. In the center of the leaf there are numerous cells that make up the water-storage parenchyma containing mucus and water. $P$. maritima is species with a high occurrence of arbuscular mycorrhiza (Veselkin et al. 2016).

Triglochin maritima - euhalophyte, a Eurasian boreal species; herbaceous polycarpic perennial plant with undergroundstolons, forming small turfs with a thick rhizome. The leaves of the T. maritima are basal, fleshy, narrowly linear, grooved, with parallel venation, covered with a cuticle layer. Mesophyll has a centric structure and in the center of the leaf aerenchyma there are large intercellular spaces. T. maritima is non-mycorrhizal species (Veselkin et al. 2016).

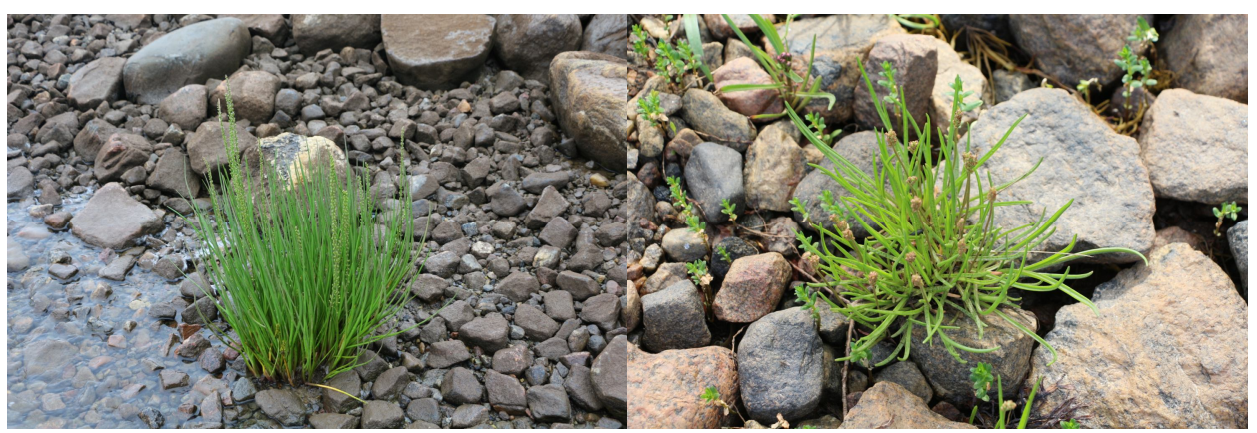

Fig. 2. Triglochin maritima L.

Fig. 3. Plantago maritima L. 


\section{Measurements}

In the middle part of each sample plot, soil and plant samples were collected to determine the content of heavy metals. At a distance of 2-3 meters from the seashore line, soil samples without the vegetation cover was collected, as well as 5 plants of each species with basal substrate.

\section{Measurements of the heavy metals content in a plant and soil}

The metal concentration in the soil and plant organs (roots, leaves, stems) was estimated using the atomic absorption method (the atomic absorption spectrophotometer AA-7000 with a flame atomizer, Shimadzu 7000 (Japan). The samples (0.2 g) were first dissolved in a mixture of concentrated acids $\left(\mathrm{HNO}_{3}, \mathrm{HCl}\right.$, in the ratio $3: 1)$ in the microwave digestion system (speed wave four, Berghof, Germany). All the tests of heavy metal content were performed using the certified equipment of the Shared Use Centre «Analytical laboratory» of Forest Research Institute of the

\section{Measurements of salinity of water and soil}

Field seawater salinity was determined using a refractometer (RHS-10ATC). The degree of soil salinity was estimated by the mass fraction (\%) of dry (dense) aqueous
Karelian Research Centre of the RAS (ISO 11466:1995, NBN EN 13657:2002, ISO 11407:1998, ISO 20280:2007). All measurements were done in triplicate.

The coefficient of biological absorption (CBA) of metal by a whole plant was calculated as a ratio of the metal content in the plant (metal content in the roots and aboveground organs) to the metal content in the soil and sea water (Polynov 1956, Batalov et al. 1991). The higher value of the CBA, the more intensively the element is absorbed by the plant (Polynov 1956).

extract residue, the content of organic matter was determined by the method according to I.V. Tyurin (Vorobeva 2006).

\section{Measurements of ion-exchange capacity and swelling coefficient of plant cell wall}

The swelling coefficient $\left(\mathrm{K}_{\mathrm{cw}}\right)$ is a quantitative characteristic of the penetrability of the cell wall polymer matrix which determents the elasticity of the cell wall. Swelling determines cell wall hydraulic conductivity. The cell wall swelling depends on the degree of crosslinking of the polymers, the total number of functional

\section{Statistical analysis}

Data analysis was performed using a SAS software (version 9.2, SAS Institute, Cary, NC). The MIXED procedure for analysis of variance was used to determine statistical differences $(\mathrm{P}<0.05)$ from groups and their ionization constant, concentration and $\mathrm{pH}$ of the external solution (Meychik 2007). The ion-exchange capacity, sorption capacity (S), dissociation constant $\left(\mathrm{pK}_{\mathrm{a}}\right)$ and coefficient of swelling $\left(\mathrm{K}_{\mathrm{cw}}\right)$ of leaf and root cell wall were investigated by a method of potentiometric titration (Terebova et al. 2018).

plants. Initially, the data were tested for homogeneity of variance and normality, although, violations were found. Average values are reported with transformed lettering according to Fisher's LSD at $\mathrm{P} \leq 0.05$. 


\section{Results}

The content of elements in soils and sea water of the study area

The content of metals in soil of the study area is presented in Table 1. The soil salinity of Lebyazhya Bay (SP1) was medium $(1.9 \%)$, while at the location in the exit of Lebyazhya Bay (SP2) it was slightly less $(1.1 \%)$. The lowest salinity $(0.6 \%)$ was registered in the area of entrance to Keretskaya Bay (SP3). The organic matter content in soil samples from Lebyazhya Bay (SP1) accounted for $0.8 \%$, and in the other two locations $-0.4 \%$. The slightly acid reaction (3.48-4.06) was recorded for littoral soil from all sample plots. The determination of metabolic acidity showed that within whole studied area there is a leveling of the difference between values of aqueous and salt $\mathrm{pH}$. Thus, the content of heavy metals in the soil of the studied area did not exceed the permissible concentrations and was lower than the clarke and background values (Table 1). Moreover, studied area is represented by littoral soils or marsh primitive soils at the initial stage of soil formation. These soils are characterized by poorly developed profiles, lack of differentiation into horizons (AC (C)), low humus content (0.13-1.18\%), low absorption capacity $\left(15-26 \mathrm{cmol}_{+} \mathrm{kg}^{-1}\right)$, neutral and slightly acidity, and low iron content (0.1\%) (Oreshnikova et al. 2012). The highest content of the most analyzed metals was observed at the location of SP1.

\begin{tabular}{|l|c|c|c|c|c|c|c|c|c|c|}
\hline Metal & SP1 & SP2 & SP3 & M & $\boldsymbol{\sigma}$ & $\min$ & $\max$ & $\begin{array}{c}\text { clarke } \\
*\end{array}$ & $\begin{array}{c}\text { back- } \\
\text { ground } \\
* *\end{array}$ & $\begin{array}{c}\text { APC } \\
* * *\end{array}$ \\
\hline $\mathrm{Fe}$ & 16131 & 9149 & 11794 & 12359 & 3525 & 6452 & 18684 & - & - & 46500 \\
\hline $\mathrm{Mn}$ & 143.14 & 94.44 & 130.81 & 122.80 & 25 & 55.70 & 191.90 & 850 & - & 1500 \\
\hline $\mathrm{Zn}$ & 17.25 & 11.60 & 17.65 & 15.50 & 3 & 8.60 & 25.30 & 50 & 62 & 150 \\
\hline $\mathrm{Cu}$ & 24.54 & 6.90 & 8.57 & 13.34 & 10 & 4.97 & 14.93 & 20 & 18 & 35 \\
\hline $\mathrm{Ni}$ & 9.89 & 6.59 & 12.71 & 9.73 & 3 & 5.07 & 20.11 & 40 & 30 & 30 \\
\hline $\mathrm{Pb}$ & 1.57 & 3.10 & 2.81 & 2.50 & 1 & 0.89 & 4.44 & 10 & 15 & 30 \\
\hline
\end{tabular}

Table 1. The metal content in the soil of study area on the White Sea littoral zone. Notes: $\mathrm{M}$-mean value; $\sigma$ - standard deviation; $\min$ - minimum; max - maximum value; * - clarke of heavy metal in the earth's crust (Vinogradov 1957); ** - Background values of heavy metals in bottom sediments of the seas (Novikov 2017); *** - APC - approximately permissible concentrations for uncontaminated bottom sediments according to SFT for $\mathrm{Zn}, \mathrm{Cu}, \mathrm{Ni}$ and $\mathrm{Pb}$ (Ilyin et al. 2015).

Seawater in the study area was characterized by different levels of salinity and the associated content of chloride ions and mineralization. The highest salinity of seawater up to $20 \%$ with the content of chloride ions - $5 \mathrm{~g} \mathrm{l}^{-1}$ and mineralization $13.46 \mathrm{~g} \mathrm{l}^{-1}$ was registered at the location of SP1. For the samples of seawater from location SP3 the lowest values of salinity
(0 \%o) were obtained as well as the chloride ion content $\left(0.56 \mathrm{~g} \mathrm{l}^{-1}\right)$ and mineralization $\left(1.14 \mathrm{~g} \mathrm{l}^{-1}\right)$, which is associated with the presence of freshwater outlets (see Table 2).

Seawater in the study area was contaminated with $\mathrm{Fe}$ (3.8 of MPC), Ni (55 of MPC), Co (1.7 of MPC) and Al (1.7 of MPC) (Table 2). 


\begin{tabular}{|c|c|c|c|c|c|c|c|}
\hline & SP1 & SP2 & SP3 & $\mathbf{M}$ & $\boldsymbol{\sigma}$ & $\begin{array}{l}\text { Back- } \\
\text { ground }\end{array}$ & MPC $^{* *}$ \\
\hline $\mathrm{NO}^{3-}, \mathrm{mg} \mathrm{l}^{-1}$ & 34.43 & 30.95 & 7.81 & 24.39 & 14.47 & - & 39 \\
\hline $\mathrm{Cl}^{-}, \mathrm{mg} \mathrm{l}^{-1}$ & 5.00 & 3.46 & 0.56 & 3.01 & 2.25 & $>2.5$ & - \\
\hline $\mathrm{C}_{\mathrm{org}}, \mathrm{mg} \mathrm{l}^{-1}$ & 29.19 & 18.08 & 46.00 & 31.09 & 14.05 & - & - \\
\hline $\begin{array}{l}\text { mineralization, } \\
\mathrm{g} \mathrm{l}^{-1}\end{array}$ & 13.46 & 12.48 & 1.14 & 9.03 & 6.85 & - & - \\
\hline $\mathrm{Fe}, \mathrm{mg} \mathrm{l}^{-1}$ & 0.1621 & 0.1396 & 0.2769 & 0.1929 & 0.074 & 0.01 & 0.05 \\
\hline $\mathrm{Mn}, \mathrm{mg} \mathrm{l}^{-1}$ & 0.0074 & 0.0149 & 0.0201 & 0.0141 & 0.006 & 0.002 & 0.05 \\
\hline $\mathrm{Zn}, \mathrm{mg} \mathrm{l}^{-1}$ & 0.0029 & 0.0032 & 0.0047 & 0.0036 & 0.001 & 0.01 & 0.05 \\
\hline $\mathrm{Ni}, \mathrm{mg} \mathrm{l}^{-1}$ & 1.3576 & 0.2871 & 0.0017 & 0.5488 & 0.715 & 0.002 & 0.01 \\
\hline $\mathrm{Cu}, \mathrm{mg} \mathrm{l}^{-1}$ & 0.0017 & 0.0016 & 0.0020 & 0.0018 & 0.000 & 0.003 & 0.005 \\
\hline $\mathrm{Co}, \mathrm{mg} \mathrm{l}^{-1}$ & 0.0008 & 0.0255 & 0.0003 & 0.0088 & 0.014 & 0.0005 & 0.005 \\
\hline $\mathrm{Cr}, \mathrm{mg} \mathrm{l}^{-1}$ & 0.0029 & 0.0011 & 0.0015 & 0.0018 & 0.001 & 0.0002 & $0.02-0.07$ \\
\hline $\mathrm{Al}, \mathrm{mg} \mathrm{l}^{-1}$ & 0.0894 & 0.0591 & 0.0529 & 0.0671 & 0.020 & 0.01 & 0.04 \\
\hline $\mathrm{Pb}, \mathrm{mg} \mathrm{l}^{-1}$ & 0.0063 & 0.0046 & 0.0004 & 0.0038 & 0.003 & 0.00003 & 0.01 \\
\hline $\mathrm{Cd}, \mathrm{mg} \mathrm{l}^{-1}$ & 0.0001 & 0.0083 & 0.0001 & 0.0028 & 0.005 & 0.0001 & 0.01 \\
\hline salinity, \%o & 20 & 7 & 0 & $5-31$ & - & - & - \\
\hline $\mathrm{pH}$ & $8.02 \pm 0.9$ & $7.62 \pm 0.6$ & $7.58 \pm 0.5$ & 7.74 & - & - & - \\
\hline
\end{tabular}

Table 2. The content of elements in seawater in the study area on the White Sea littoral zone. Notes: $\mathrm{M}$ - mean value; $\sigma$ - standard deviation; ${ }^{*}$ - background values of analyzed parameters in the seawater ([1] - Order of the Ministry 2016); ${ }^{* *}$ MPC - maximum permissible concentrations (MPC) in seawater of fishery facilities ([1] - Order of the Ministry 2016).

The content of $\mathrm{Cd}, \mathrm{Pb}, \mathrm{Mn}$ and $\mathrm{Cr}$ in the seawater of the studied area exceeded the natural background but was below the maximum permissible concentrations. The contents of $\mathrm{Zn}$ and $\mathrm{Cu}$ were lower in ana- lyzed samples of sea water and did not exceed the natural background while content of nutrients - carbon and nitrates in seawater - was significantly high (Table 2).

\section{The content of heavy metals in Plantago maritima and Triglochin maritima}

In conditions of littoral poor soils and contaminated seawater plant species $P$. maritima and T. maritima accumulated elements (Table 3).

Thus, halophytes of the littoral zone $P$. maritima and T. maritima actively accumulated $\mathrm{Fe}, \mathrm{Mn}, \mathrm{Ni}, \mathrm{Cu}, \mathrm{Zn}, \mathrm{Pb}$ by whole the plant and CBA of these metals was $\geq 1$. The Fe content in studied halophytes was 3-4 times higher than the critical level of Fe in plants according to Pendias (2010). The majority of the accumulated metals was observed in the roots $(50-70 \%$ of the total element content in the plant) in comparison with the aboveground organs (30$50 \%$ ), with the exception of iron. Over $80 \%$ of the total Fe in studied species accumulated in the roots (Table 3 ). However, a slight difference between the plant species was distinguished: T. maritima accumulated $\mathrm{Fe}$ and $\mathrm{Ni}$ in high amounts while $P$. maritima accumulated rather biophilic metals such as $\mathrm{Zn}$ and $\mathrm{Cu}$. 


\begin{tabular}{|c|c|c|c|c|c|c|}
\hline \multicolumn{7}{|c|}{ Plantago maritima } \\
\hline & Fe & Mn & Zn & $\mathrm{Cu}$ & $\mathbf{N i}$ & $\mathbf{P b}$ \\
\hline $\begin{array}{l}\text { M plant, } \\
\text { mg kg }^{-1}\end{array}$ & $\mathbf{1 3 3 5 1} \pm 1037$ & $162.46 \pm 30.65$ & $42.67 \pm 2.95$ & $21.16 \pm 2.23$ & $15.61 \pm 7.07$ & $\mathbf{3 . 2 5} \pm 0.01$ \\
\hline $\begin{array}{l}\mathrm{M} \\
\text { aboveground } \\
\text { organs }\end{array}$ & $\mathbf{2 5 8 0} \pm 258$ & $\mathbf{5 0 . 5 9} \pm 14.25$ & $19.02 \pm 4.85$ & $\mathbf{8 . 0 7} \pm 2.45$ & $\mathbf{3 . 1 9} \pm 0.89$ & $\mathbf{1 . 3 5} \pm 0.15$ \\
\hline $\mathrm{M}$ roots & $\mathbf{1 0 7 7 1} \pm 2147$ & 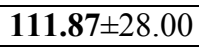 & $23.65 \pm 3.96$ & $\mathbf{1 3 . 0 8} \pm 1.45$ & $\mathbf{1 2 . 4 1} \pm 1.20$ & $\mathbf{1 . 9 1} \pm 0.63$ \\
\hline $\begin{array}{l}\text { CBA } \\
\text { aboveground } \\
\text { organs }\end{array}$ & $\mathbf{0 . 2 1} \pm 0.07$ & $\mathbf{0 . 3 9} \pm 0.02$ & $\mathbf{1 . 2 3} \pm 0.45$ & $1.27 \pm 0.02$ & $\mathbf{1 . 2 3} \pm 0.68$ & $\mathbf{0 . 5 2} \pm 0.03$ \\
\hline CBA roots & $\mathbf{0 . 7 6} \pm 0.09$ & $\mathbf{0 . 8 2} \pm 0.14$ & $\mathbf{1 . 5 7} \pm 0.25$ & $\mathbf{2 . 0 2} \pm 0.26$ & $\mathbf{0 . 3 4} \pm 0.05$ & \begin{tabular}{|l}
$\mathbf{0 . 7 7} \pm 0.11$ \\
\end{tabular} \\
\hline $\begin{array}{l}\text { CBA whole } \\
\text { plant }\end{array}$ & $\mathbf{0 . 9 7} \pm 0.10$ & $\mathbf{1 . 2 1} \pm 0.10$ & $\mathbf{2 . 8 1} \pm 0.52$ & $\mathbf{3 . 2 9} \pm 0.50$ & $\mathbf{1 . 5 7} \pm 0.07$ & $1.30 \pm 0.46$ \\
\hline $\begin{array}{l}\text { Critical level } \\
\text { of element } \\
\text { in plants*, } \\
\mathrm{mg} \mathrm{kg}^{-1}\end{array}$ & $>500$ & $300-500$ & $>100$ & $20-100$ & $10-100$ & $20-300$ \\
\hline \multicolumn{7}{|c|}{ Triglochin maritima } \\
\hline & $\mathbf{F e}$ & Mn & $\mathbf{Z n}$ & $\mathbf{C u}$ & $\mathbf{N i}$ & $\mathbf{P b}$ \\
\hline $\begin{array}{l}\text { M plant, } \\
\text { mg kg}^{-1}\end{array}$ & $\mathbf{2 2 0 2 1} \pm 1136$ & $134.30 \pm 27.75$ & $\mathbf{2 6 . 0 1} \pm 4.63$ & $14.35 \pm 2.70$ & $\mathbf{3 6 . 0 1} \pm 6.71$ & $\mathbf{2 . 8 8} \pm 0.31$ \\
\hline $\begin{array}{l}\mathrm{M} \\
\text { aboveground } \\
\text { organs }\end{array}$ & $3241 \pm 115$ & $\mathbf{5 9 . 8 6} \pm 10.23$ & $10.88 \pm 3.85$ & $\mathbf{4 . 4 6} \pm 1.15$ & $14.18 \pm 4.74$ & $\mathbf{0 . 8 5} \pm 0.10$ \\
\hline $\mathrm{M}$ roots & $\mathbf{1 8 7 8 0} \pm 2125$ & $\mathbf{7 4 . 4 4} \pm 15.10$ & $15.12 \pm 4.20$ & $\mathbf{9 . 8 9} \pm 2.78$ & $\mathbf{2 1 . 8 2} \pm 2.96$ & $\mathbf{2 . 0 3} \pm 0.56$ \\
\hline $\begin{array}{l}\text { CBA } \\
\text { aboveground } \\
\text { organs }\end{array}$ & $\mathbf{0 . 3 0} \pm 0.07$ & $\mathbf{0 . 6 0} \pm 0.08$ & $\mathbf{0 . 8 0} \pm 0.09$ & $\mathbf{0 . 6 1} \pm 0.20$ & $\mathbf{1 . 4 6} \pm 0.90$ & $\mathbf{0 . 4 8} \pm 0.23$ \\
\hline CBA roots & $\mathbf{1 . 7 8} \pm 0.25$ & $\mathbf{0 . 7 1} \pm 0.08$ & $\mathbf{1 . 0 4} \pm 0.02$ & $\mathbf{1 . 3 0} \pm 0.05$ & $\mathbf{2 . 3 4} \pm 0.15$ & $\mathbf{1 . 0 3} \pm 0.12$ \\
\hline $\begin{array}{l}\text { CBA whole } \\
\text { plant }\end{array}$ & $\mathbf{2 . 0 8} \pm 0.31$ & $\mathbf{1 . 3 1} \pm 0.15$ & $\mathbf{1 . 8 4} \pm 0.18$ & $1.91 \pm 0.23$ & $\mathbf{3 . 8 0} \pm 1.12$ & $\mathbf{1 . 5 1} \pm 0.07$ \\
\hline
\end{tabular}

Table 3. The average values of the element contents $(M)$ and the coefficient of biological absorption (CBA) of metals by roots, aboveground organs and whole plant of Plantago maritima and Triglochin maritima. Notes: *Critical level of element in plants, $\mathrm{mg} \mathrm{kg}^{-1}$ (Pendias 2010).

\section{Cell wall properties of leaves and roots of Plantago maritima and Triglochin maritima}

According to results of the study, it was found that four types of ion-exchange or functional groups are included in the structure of the cell walls of the leaves and roots of the studied halophytes. For these groups, the values of ionization constants (pKa) were calculated (Meychik 2007) and it was established that they included anion exchange amino groups $(\mathrm{pKa} \sim 1.5-4)$ and three cation-exchange groups: carbox- yl groups of $\alpha$-D-polygalacturonic acids (COOH PGUK) (pKa 5-6), carboxyl groups of hydroxycinnamic acids $(\mathrm{COOH}$ HCA) (pKa 7-8) and phenolic $\mathrm{OH}-$ groups ( $\mathrm{pKa} \sim 9-10)$.

The number of groups was evaluated by the value of sorption capacity $(\mathrm{S}, \mu \mathrm{mol}$ $\mathrm{g}^{-1}$ dry weight of cell walls). The maximum $S$ values corresponded to the total number of ion-exchange groups in the structure of 
the plant cell walls. $\mathrm{S}$ value of the cell wall, can indicate its ability to accumulate various elements. Value of $\mathrm{S}$ of the leaf cell wall was $3570-3700 \mu \mathrm{mol} \mathrm{g}{ }^{-1}$ of dry cell weight for P. maritima and $2710-$
$3070 \mu \mathrm{mol} \mathrm{g} \mathrm{g}^{-1}$ of dry cell weight - for T. maritima (Table 4). Under conditions of $20 \%$-salinity of seawater, $\mathrm{S}$ of the leaf cell wall was higher than at $0 \%$-salinity.

\begin{tabular}{|l|c|c|c|c|}
\hline \multirow{2}{*}{ Type of group } & \multicolumn{4}{|c|}{ Amount of groups, S $\boldsymbol{\mu m o l}^{\mathbf{- 1}}$ dry cell weight } \\
\cline { 2 - 5 } & \multicolumn{2}{|c|}{ Plantago maritima } & \multicolumn{2}{c|}{ Triglochin maritima } \\
\hline Water salinity & $20 \%$ & $0 \%$ & $20 \%$ & $0 \%$ \\
\hline Amino groups & $\begin{array}{c}250 \pm 20^{\mathrm{a}} \\
(6 \%)\end{array}$ & $\begin{array}{c}450 \pm 30^{\mathrm{b}} \\
(13 \%)\end{array}$ & $\begin{array}{c}170 \pm 30^{\mathrm{a}} \\
(5 \%)\end{array}$ & $\begin{array}{c}450 \pm 20^{\mathrm{b}} \\
(17 \%)\end{array}$ \\
\hline COOH PGUC & $\begin{array}{c}650 \pm 30^{\mathrm{a}} \\
(18 \%)\end{array}$ & $\begin{array}{c}720 \pm 50^{\mathrm{a}} \\
(20 \%)\end{array}$ & $\begin{array}{c}1800 \pm 50^{\mathrm{a}} \\
(59 \%)\end{array}$ & $\begin{array}{c}1000 \pm 40^{\mathrm{b}} \\
(37 \%)\end{array}$ \\
\hline COOH HCA & $\begin{array}{c}1650 \pm 70^{\mathrm{a}} \\
(45 \%)\end{array}$ & $\begin{array}{c}1430 \pm 60^{\mathrm{b}} \\
(40 \%)\end{array}$ & $\begin{array}{c}850 \pm 90^{\mathrm{a}} \\
(28)\end{array}$ & $\begin{array}{c}1100 \pm 100^{\mathrm{a}} \\
(40)\end{array}$ \\
\hline Phenolic OH-group & $\begin{array}{c}1150 \pm 30^{\mathrm{a}} \\
(31 \%)\end{array}$ & $\begin{array}{c}970 \pm 20^{\mathrm{b}} \\
(27 \%)\end{array}$ & $\begin{array}{c}250 \pm 25^{\mathrm{a}} \\
(8 \%)\end{array}$ & $\begin{array}{c}160 \pm 70^{\mathrm{b}} \\
(6 \%)\end{array}$ \\
\hline $\begin{array}{l}\text { Total number of } \\
\text { functional groups }\end{array}$ & $\mathbf{3 7 0 0} \pm \mathbf{7 0}^{\mathrm{a}}$ & $\mathbf{3 5 7 0} \pm \mathbf{9 0}$ & $\mathbf{3 0 7 0} \pm \mathbf{5 0}$ & $\mathbf{2 7 1 0} \pm \mathbf{5 0}$ \\
\hline
\end{tabular}

Table 4. The content of ion-exchange groups and group ratio in the leaf cell walls of Plantago maritima and Triglochin maritima (\%). Notes: Data presented with different letters in the same column indicate a significant difference at $\mathrm{p} \leq 0.05$ from halophyte plants in different salinity to Fisher's LSD test. Data were determined in 5 replications, standard deviation values are given after \pm . Abbreviations: COOH PGUC - carboxyl group of $\alpha$-D-polygalacturonic acid, COOH HCA - carboxyl group of hydroxycinnamic acids.

In the studied halophytes, the largest amounts of the leaf cell wall groups were carboxyl groups of hydroxycinnamic acids (40-45\% in P. maritima), polygalacturonic acid carboxyl groups $(37-59 \%$ in $T$. maritima) and phenolic $\mathrm{OH}$-groups (37-31\% in P. maritima) (Table 4). Low percentage of phenolic $\mathrm{OH}$-groups $(6-8 \%)$ were registered in leaf cell wall of $T$. maritima. The content of amino groups in leaf cell wall of both halophytes was $5-17 \%$. The salinity conditions of seawater influenced the number of groups of the leaf cell wall. For $P$. maritima the amount of $\mathrm{COOH} \mathrm{HCA}$ and phenolic $\mathrm{OH}$-groups of the leaf cell wall was 1.2 times higher at a salinity of $20 \%$ in comparison with $0 \%$ salinity level. For T. maritima the amount of $\mathrm{COOH}$ PGUC as well as the phenolic $\mathrm{OH}$-groups of the leaf cell wall was $1.8-1.6$ times higher at $20 \%$-salinity. On the contrary, the number of amino groups decreased in 1.5-2 times in the leaf cell wall of both studied plants with an increasing salinity of seawater (Table 4).

The total S of root cell wall was lower than leaf cell wall and accounted for 2310 $-2350 \mu \mathrm{mol} \mathrm{g}{ }^{-1}$ of dry cell weight for P. maritima and $1160-1250 \mu \mathrm{mol} \mathrm{g}$ of dry cell weight - for T. maritima. Root cell wall S of $P$. maritima was higher compared with $T$. maritima. No significant relation was found between salinity level and sorption capacity of root cell wall of both studied species (Table 5). For P. maritima higher number of root cell wall groups was registered for $\mathrm{COOH}$ PGUC groups (34$36 \%$ ) and phenolic OH-groups (36-43\%) 
while for T. maritima $\mathrm{COOH} \mathrm{HCA}$ groups (38-39\%) were prevailed. Salinity had practically no effect on the change in the number of functional groups in the root cell wall of both halophytes. Only a decrease in the number of phenolic $\mathrm{OH}-$ groups in the root cell wall of $P$. maritima and the amino groups of root cell wall of
T. maritima with an increasing salinity of sea water was registered (Table 5). In total, the content of amino groups (from total group content) in the root cell wall was 2 times higher compared with leaf cell wall. At the same time, the number of amino groups was maximal in the root cell wall of T. maritima (Table 5).

\begin{tabular}{|c|c|c|c|c|}
\hline \multirow{3}{*}{$\begin{array}{l}\text { Type of group } \\
\text { Water salinity }\end{array}$} & \multicolumn{4}{|c|}{ Amount of groups, $S \boldsymbol{\mu m o l ~ \mathrm { g } ^ { - 1 }}$ dry cell weight } \\
\hline & \multicolumn{2}{|c|}{ Plantago maritima } & \multicolumn{2}{|c|}{ Triglochin maritima } \\
\hline & $20 \%$ & $0 \%$ & $20 \%$ & $0 \%$ \\
\hline Amino groups & $\begin{array}{c}250 \pm 30^{\mathrm{a}} \\
(11 \%)\end{array}$ & $\begin{array}{c}250 \pm 20^{\mathrm{a}} \\
(11 \%)\end{array}$ & $\begin{array}{c}350 \pm 30^{\mathrm{a}} \\
(30 \%)\end{array}$ & $\begin{array}{c}450 \pm 20^{b} \\
(36 \%)\end{array}$ \\
\hline COOH PGUC & $\begin{array}{c}820 \pm 50^{\mathrm{a}} \\
(36 \%)\end{array}$ & $\begin{array}{c}810 \pm 50^{\mathrm{a}} \\
(34 \%)\end{array}$ & $\begin{array}{c}90 \pm 20^{\mathrm{a}} \\
(8 \%)\end{array}$ & $\begin{array}{c}100 \pm 30^{\mathrm{a}} \\
(8 \%)\end{array}$ \\
\hline $\mathrm{COOH} \mathrm{HCA}$ & $\begin{array}{c}400 \pm 60^{\mathrm{a}} \\
(17 \%)\end{array}$ & $\begin{array}{c}290 \pm 100^{\mathrm{a}} \\
(12 \%)\end{array}$ & $\begin{array}{c}450 \pm 70^{\mathrm{a}} \\
(39 \%)\end{array}$ & $\begin{array}{c}470 \pm 80^{\mathrm{a}} \\
(38 \%)\end{array}$ \\
\hline Phenolic OH-group & $\begin{array}{c}840 \pm 50^{\mathrm{a}} \\
(36 \%)\end{array}$ & $\begin{array}{c}1000 \pm 50^{b} \\
(43 \%)\end{array}$ & $\begin{array}{c}270 \pm 30^{\mathrm{a}} \\
(23 \%)\end{array}$ & $\begin{array}{c}230 \pm 70^{\mathrm{a}} \\
(18 \%)\end{array}$ \\
\hline $\begin{array}{l}\text { Total number of } \\
\text { functional groups }\end{array}$ & $\mathbf{2 3 1 0} \pm 50^{\mathrm{a}}$ & $2350 \pm 100^{a}$ & $1160 \pm 50^{\mathrm{a}}$ & $1250 \pm 50^{\mathrm{a}}$ \\
\hline
\end{tabular}

Table 5. The content of ion-exchange groups (\%) and group ratios in root cell walls of Plantago maritima and Triglochin maritima. Notes: Data presented with different letters in the same column indicate a significant difference at $\mathrm{p} \leq 0.05$ from halophytes plants in different salinity to Fisher's LSD test. Data were determined in 5 replications, standard deviation values are given after \pm . Abbreviations: $\mathrm{COOH}$ PGUC - carboxyl group of $\alpha$-D-polygalacturonic acid, COOH HCA carboxyl group of hydroxycinnamic acids.

$\mathrm{K}_{\mathrm{cw}}$ in water of the leaf and root cell wall of the studied halophytes in comparison with $\mathrm{K}_{\mathrm{cw}}$ of terrestrial plants is presented in Table $6 . \mathrm{K}_{\mathrm{cw}}$ in water of $P$. maritima cell wall was higher compared to T. maritima: $9.92-6.38$ and 4.37-2.76 g $\mathrm{H}_{2} \mathrm{O} \mathrm{g}^{-1}$ dry cell weight, respectively. In both cases, the swelling of the leaf cell wall was 2 times higher than the swelling of the root cell wall. However, the swelling of the leaf cell wall of the halophyte was significantly higher (on average 7 times) than leaf cell wall of terrestrial plants (Table 6).
$\mathrm{K}_{\mathrm{cw}}$ of studied plants was higher in the leaf cell wall (1-14 $\mathrm{g} \mathrm{H}_{2} \mathrm{O} \mathrm{g}^{-1}$ dry cell) weight than in the root cell wall (1-6 g $\mathrm{H}_{2} \mathrm{O} \mathrm{g}^{-1}$ dry cell weight) of dry cell weight) depending on the $\mathrm{pH}$ (Fig. 4.). Cell wall swelling increased with increasing $\mathrm{pH}$ of the solution and in all cases, values of swelling coefficient were minimal in the acidic range. With increasing salinity of sea water (up to $20 \%$ ), the swelling of the cell wall of the halophyte root increased, especially in P. maritima (Fig. 4). 


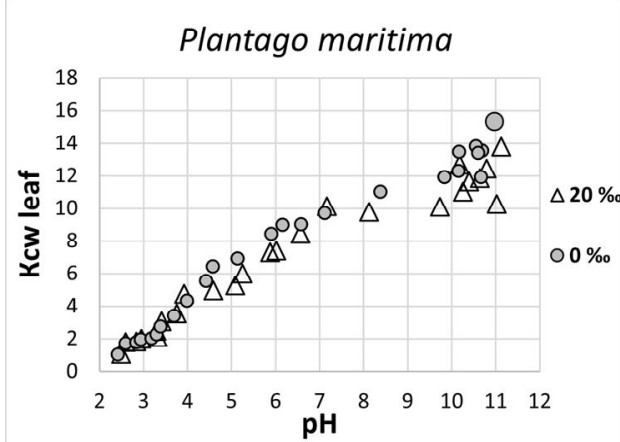

Triglochin maritima

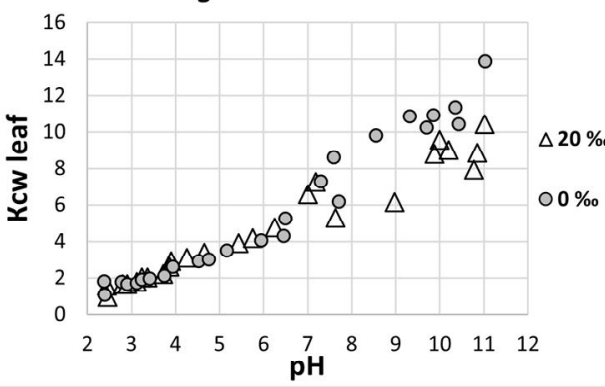

Plantago maritima

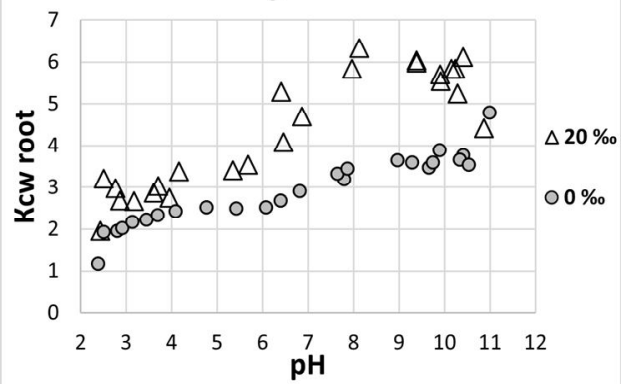

Triglochin maritima

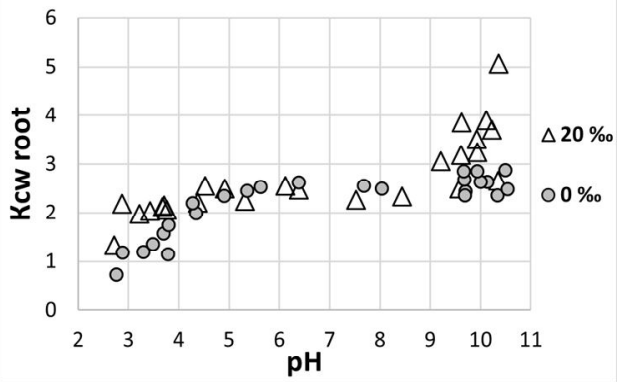

Fig. 4. Dependence of the swelling coefficient $\mathrm{K}_{\mathrm{cw}}\left(\mathrm{g} \mathrm{H}_{2} \mathrm{O} \mathrm{g}^{-1}\right.$ dry cell weight) of the cell wall in leaves and roots of Plantago maritima and Triglochin maritima on the $\mathrm{pH}$ of the solution at different salinity.

\begin{tabular}{|c|c|c|}
\hline Plant species & $K_{\mathrm{cw}}$ leaf & $K_{\mathrm{cw}}$ root \\
\hline Plantago maritima* & $9.92 \pm 1.25$ & $\mathbf{4 . 3 7} \pm 0.45$ \\
\hline Triglochin maritima* & $\mathbf{6 . 3 8} \pm 1.05$ & $\mathbf{2 . 7 6} \pm 0.33$ \\
\hline${ }^{1}$ Suaeda altissima* & - & $\mathbf{3 . 7 0} \pm 1.40$ \\
\hline${ }^{2}$ Pinus sylvestris** & $\mathbf{1 . 5 0} \pm 0.12$ & - \\
\hline${ }^{2}$ Betula nana ${ }^{* *}$ & $\mathbf{1 . 9 3} \pm 0.20$ & - \\
\hline${ }^{2}$ Dryas octopetala** & $\mathbf{1 . 4 5} \pm 0.15$ & - \\
\hline${ }^{2}$ Salix polaris $* *$ & $\mathbf{2 . 6 0} \pm 0.13$ & - \\
\hline${ }^{2}$ Cassiope tetragona $* *$ & $\mathbf{0 . 8 3} \pm 0.14$ & - \\
\hline
\end{tabular}

Table 6. Values of swelling coefficient $\mathrm{K}_{\mathrm{cw}}$ in water of leaf cell wall of coastal and terrestrial plants. Notes: ${ }^{*}$ - coastal plant; ${ }^{* *}$ - terrestrial plant; 1 - according to Terebova et al. 2018; 2 - according to Meychik 2001.

\section{Discussion}

Dominant plant species $P$. maritima and T. maritima of the White Sea littoral grew in the estuary of the River Keret on slightly saline, mineral-poor soils and in seawater elements-rich such as Fe (3.8 of MPC), Ni (55 of MPC), Co (1.7 of MPC), $\mathrm{Al}$ (1.7 of MPC), carbon and nitrogen. The maximum content of most of the studied 
elements was established at SP1 in Lebyazhya Bay. This is probably due to the partial proximity of the Lebyazhya Bay a seashore of the White Sea, which contributes to the accumulation of numerous elements.

According to Ilyin et al. (2015), nutrients and pollutants enter the White Sea through the drains of large rivers (the Onega River, the Northern Dvina River, the Kem River, the Nizhny Vyg River, the Verkhny Vyg River, the Keret River). The volume of sewage discharged into surface water bodies of the White Sea basin in 2017 amounted to 76.18 millions $\mathrm{m}^{3}$, including 18.87 millions $\mathrm{m}^{3}$ of waste from the tailing dump of the mining plant Karelsky Okatysh ([2] - State report 2018). The main pollutants in the water of the tailing dump of this mining plant are $\mathrm{Ni}(0.017-$ $\left.0.025 \mathrm{mg} \mathrm{l}^{-1}\right)$, Mn (0.432-0.650 $\left.\mathrm{mg} \mathrm{l}^{-1}\right)$, $\mathrm{Zn}\left(0.051-0.075 \mathrm{mg} \mathrm{l}^{-1}\right)$, while in the soils of the tailing dump Fe (39 505-45 $120 \mathrm{mg}$ $\mathrm{kg}^{-1}$ ) prevails (Terebova et al. 2017). According to results of present study, significant accumulation of $\mathrm{Ni}$ and $\mathrm{Fe}$ were established in the seawater of Lebyazhye and Keretskaya Bays. Moreover, the other pollutants discharge into the water bodies of the White Sea basin in huge amounts such as the follows: $\mathrm{Mn}$ (2.5 tons), $\mathrm{Mg}$ (524 tons), nitrites (8.5 tons), suspended solids (425 tons), sulfates (12602 tons) and phenols (0.5 tons) ([2] - State report 2018).

According to the obtained results, the studied halophytic plants growing on unsorted sandy littoral soil intensively accumulate heavy metals in whole plant bodies. Coefficient of biological absorption (CBA) for $\mathrm{Fe}, \mathrm{Mn}, \mathrm{Ni}, \mathrm{Cu}, \mathrm{Zn}, \mathrm{Pb}$ was $>1$. In fact, the metals were accumulated in roots more $(50-70 \%$ from the total content of a metal in a plant) than in aboveground organs $(30-50 \%)$. However, $80 \%$ of the total $\mathrm{Fe}$ in the plant was accumulated in the roots. This could be because both species of studied halophytes are perennials plants that retain well-developed underground organs for a long time (Sergienko et al. 2017).
Therefore, they accumulate the metals during several consecutive seasons.

However, in spite of species-specific differences, the accumulation of heavy metals has a certain general tendency. According to the known data of CBA-values, several groups of elements are distinguished: 1 . $\mathrm{Zn}, \mathrm{Cu}, \mathrm{Pb}$ have an average degree of absorption (Stoltz and Greger 2002, Pulford and Watson 2003, Zhivotovsky et al. 2011), 2. Mn, Ni are weakly uptaken (Titov et al. 2011) and 3. Fe is difficult to absorb by plants (Vandecasteele et al. 2004). Indeed, our earlier study (Terebova et al. 2017) showed, that in technogenic landscapes, $\mathrm{Fe}$ and Ni were very weakly accumulated by willow, a phytoremediation plants $(\mathrm{CBA}<1)$. However, in this recent study, halophytic plants absorbed nickel and iron intensively. The study revealed that T. maritima has the following series of metal accumulation (calculated for the whole plant): $\mathrm{Ni}(3.80)>\mathrm{Fe}(2.08)>\mathrm{Cu}$ $(1.91)>\mathrm{Zn}(1.84)>\mathrm{Pb}(1.51)>\mathrm{Mn}(1.31)$ and for $P$. maritima the following series was registered: $\mathrm{Cu}(3.29)>\mathrm{Zn}(2.81)>\mathrm{Ni}$ $(1.57)>\mathrm{Pb}(1.30)>\mathrm{Mn}(1.21)>\mathrm{Fe}(0.97)$. Our findings could suggest that these plant species can be attributed to heavy metal accumulators in the estuary of the River Keret.

According to modern concepts, halophytes are highly resistant to the toxic effects of salts and heavy metals and can both actively uptake them from the environment (Manousaki and Kalogerakis 2011, Lokhande et al. 2011) and excrete them from their organs (Toderich et al. 2001, Manousaki et al. 2013), reducing the negative effect of pollutants.

However, there is still little known about the mechanisms of adaptation to the toxic effects of salts and heavy metals for halophytic plant species (Van Oosten and Maggio 2015). The response of the organism depends on the dose, type of contamination, salinity levels and can be multidirectional. For example, it was found for 
halophytic plant Kosteletzkya virginica (L.) C. Presl ex A. Gray that $\mathrm{Cd}$ reduced the uptake of $\mathrm{Na}$ under salt treatment and increased $\mathrm{K}$ concentration in leaves. In contrast, $\mathrm{Zn}$ increased $\mathrm{Na}$ translocation and reduced $\mathrm{K}$ levels in leaves of this species (Han et al. 2012). By increasing $\mathrm{NaCl}, \mathrm{Cd}$ accumulation was reduced but still unable to alleviate $\mathrm{Cd}$-induced growth effects. The presence of $\mathrm{NaCl}$ in conjunction with $\mathrm{Cd}$ was shown to reduce senescence, decrease oxidative stress and reduce ABA level. In this study young seedlings of Kosteletzkya virginica were exposed during 3 weeks in nutrient solution to $\mathrm{Cd} 5 \mu \mathrm{M}$ in the presence or absence of $50 \mathrm{mM} \mathrm{NaCl}$. The presence of $\mathrm{NaCl}$ partially reduced the oxidative stress induced damage in Cd-treated plants that was manifested by lower increases in lipid peroxidation and protein oxidation. Surprisingly, in this case no accumulation of $\mathrm{H}_{2} \mathrm{O}_{2}$ or $\mathrm{O}^{2 \cdot-}$ was observed. Additional salt reduced ABA accumulation in $\mathrm{Cd}+\mathrm{NaCl}$-treated leaves comparing to $\mathrm{Cd}$ alone. Also salinity reduced $\mathrm{Cd}$ accumulation already after 1 week of stress but was unable to restore shoot growth and thus did not induce any dilution effect (Han et al. 2013). This indicates that for some halophytes, the presence of $\mathrm{NaCl}$ may be required to cope with oxidative stress such as those induced by heavy metals. Similarly, significant levels of $\mathrm{Cu}, \mathrm{Cd}$, and $\mathrm{Pb}$ were found to accumulate in stems and leaves of Halimione portulacoides (L.) Aellen, a small evergreen shrub found in coastal salt marshes (Reboreda and Caçador 2007). It was demonstrated that roots of $H$. portulacoides accumulated significant amounts of $\mathrm{Zn}, \mathrm{Cu}, \mathrm{Ni}$, and $\mathrm{Co}$ and closely correlated with soil salt concentrations (Milić et al. 2012).

The most of limited physiological studies of $T$. maritima and $P$ maritima were carried out in laboratories. For example, the metabolism in relation to the tolerance to salt stress were investigated in salt-tolerant $P$. maritima and salt-sensitive $P$. media L. It was found that the activity of anti- oxidant enzymes such as CAT, POX and SOD increases with increasing salinity to $200 \mathrm{mM} \mathrm{NaCl}$ in P. maritima leaves after 7-days treatment. These results suggest that the salt-tolerant $P$. maritima showed a better protection mechanism against oxidative damage caused by salt stress by its higher induced activities of antioxidant enzymes than the salt-sensitive $P$. media (Sekmen et al. 2007).

In the field studies Markovskaya and Gulyaeva (2020) the stable states of $P$. maritima on the littoral of the White Sea were observed at high and low tides while transient states of the plants were established during tidal dynamic when not all parts of the plants are flooded. In a stable state high functional parameters of chlorophyll $a$ fluorescence $\left(\mathrm{F}_{\mathrm{V}} / \mathrm{F}_{\mathrm{M}} 0.80, \Phi_{\mathrm{PSII}} 0.30\right.$, ETR 110) and open stomata (Gs 350$450 \mu \mathrm{mol} \mathrm{m} \mathrm{m}^{-2} \mathrm{~s}^{-1}$ ) were registered for the plants. In transient states, stomata of $P$. maritima were partially closed and functional activity was inhibited: $\mathrm{F}_{\mathrm{V}} / \mathrm{F}_{\mathrm{M}}$ $0.70, \Phi_{\text {PSII }} 0.20-0.25$, ETR 70-90, Gs 50$150 \mu \mathrm{mol} \mathrm{m} \mathrm{m}^{-2} \mathrm{~s}^{-1}$ (Markovskaya and Gulyaeva 2020).

Recently, Anjum et al. (2013) demonstrated that $T$. maritima can intensely absorb $\mathrm{Hg}$, mostly by roots $(3.4-5.2 \mathrm{mg}$ $\left.\mathrm{kg}^{-1}\right)$, and leaves $\left(0.03-0.05 \mathrm{mg} \mathrm{kg}^{-1}\right)$ in Ria de Aveiro coastal lagoon. In a laboratory experiment with an increase in salinity up to $15 \mathrm{ppm}, T$. maritima multidirectionally changed in parameters such as the content of total phenols, flavonoids, proline, and vitamin $\mathrm{C}$ (Boestfleisch and Papenbrock 2017).

It was also reported, that salinity stress reduces the biomass in vegetable crops, but at the same time increases the secondary metabolite concentration (Shannon and Grieve 1998, Selmar and Kleinwächter 2013). T. maritima and P. maritima are species with apoplastic phloem loading and they use the apoplast as an intermediate accumulator of assimilates before loading into the phloem (Gamaley 2004). Thus, it can be assumed that metabolic processes 
located in the cell wall free space play a major role in the transport of metals and salts through halophyte organs.

According to obtained results the ionexchange ability of the cell wall of the leaf and root of $T$. maritima and $P$. maritima amounted of 2 710-3 070 and 3 570-3 700 for leaves; 1 160-1 250 and 2 310-2 350 $\mu \mathrm{mol} \mathrm{g}{ }^{-1}$ dry cell weight - for root, correspondingly. These are lower values, compared to the sorption capacity of the leaf cell wall of the Arctic plants (2 700-8 300 $\mu \mathrm{mol} \mathrm{g}{ }^{-1}$ dry cell weight) (Terebova et al. 2018), but higher when compared to the cell wall values of the leaf of plants of the taiga zone (1 $000-1500 \mu \mathrm{mol} \mathrm{g}{ }^{-1}$ of dry cell weight) (Galibina and Terebova 2008). The ion-exchange activity of the leaf cell wall was higher than that in root. Perhaps this is due to the high level of seawater pollution (unpolluted soils) in the sample plots, especially for nickel, iron, cobalt and aluminum. However, according to the values of the CBA, halophyte root accumulates elements more intensely than the leaf (Table 3). This is due to the fact that the halophytes $P$. maritima and $T$. maritima are perennials that retain developed underground organs for a long time (Sergienko et al. 2017). A large number of ion-exchange groups in the structure of the leaf cell wall of the halophytic species is associated with structural features and metabolism of the leaf tissues. In general, the leaves of P. maritima and T. maritima are characterized by succulent features, small cells, increasing in leaf thickness due to an increase in mesophyll layers, location of stomata on the adaxal and abaxal leaf sides, change the water storage function from surface leaf structures to specialized water parenchyma located deep inside the leaf. In addition, T. maritima has welldeveloped aerenchyma in the leaves (Gulyaeva et al. 2016).

During the study, it was found that four types of ion-exchange groups were included in the structure of the cell walls in the leaves and the roots of $P$. maritima and
T. maritima. These are anion-exchange amino groups and cation-exchange groups: carboxyl groups of $\alpha$-D-polygalacturonic acid (COOH PGUC), carboxyl groups of hydroxycinnamic acids (COOH HCA), and phenolic $\mathrm{OH}$-groups. Amino groups of the cell wall are markers of cell wall proteins. It is well-established that cell wall proteins involved in stress signaling, in detoxification and ROS scavenging. In fact, proteins involved in cell wall modification such as enzymes of phenylpropanoid biosynthetic pathway and methyltransferases involved in methylation of lignin components (Pandey et al. 2010). Also cell wall proteins take a part in carbohydrate metabolism as pentose phosphate pathway and they are proposed to be involved in biosynthesis of sugars as a part of osmotic adjustment under dehydration stress or to be involved in ROS scavenging due to production of NADPH (Pandey et al. 2010, Kosova et al. 2018).

Carboxyl groups can be part of pectic substances and hydroxycinnamic acids of the cell wall. Pectins are acidic polysaccharides enriched with galacturonic acid residues and they are characteristic components of the primary cell walls. In fact, the cation-exchange carboxyl groups of the cell wall mainly bind metals from the environment (Krzeslowska 2011). Hydroxycinnamic acids (phenolic acids) are low molecular weight phenolic compounds of the cell wall (ferulic acid, synapic acid, paracoumaric acid, caffeic acid, gallic acid, etc.) which are components of suberin, cutin and pectin polysaccharides. Due to the formation of diferulates, ferulic acid can perform a structural function in the cell walls, binding polysaccharides to each other and therefore reducing the extensibility of cell walls (Sharova 2004, Iiyama et al. 1994). Phenolic acids of cell walls can be involved in redox processes and provide neutralization of reactive oxygen species. Furthermore, phenolic-OH groups are considered as markers of phenolic compounds, mainly lignin and suberin - compo- 
nents of the secondary cell wall (Sharova 2004). According to our data, phenolic substances (high molecular weight lignin and suberin; phenolic acids) and pectins are the main components of the cell wall of the leaves and roots of the halophytes T. maritima and $P$. maritima, since the largest proportions are recorded for such ion-exchange groups as $\mathrm{COOH} \mathrm{PGUC}, \mathrm{COOH}$ HCA and phenolic OH-groups (Tables 4, 5). However, in the leaf of $P$. maritima high-molecular weight phenols are prevailed while pectin is registered at higher rates in T. maritima. Thus, these results revealed specific structural features of the cell wall of studied halophytic species.

Interestingly, the $\mathrm{pH}$ of sea water (7-8) is optimal precisely for the functioning of the carboxyl groups of hydroxycinnamic acids (COOH HCA) of the cell wall of halophyte organs with a pKa of $\sim 7-8$. It was shown that under heavy metal pollution, thickening of the cell walls of the rhizoderm in the Vicia faba root can occur due to the synthesis of callose, lignin and pectin (Krzeslowska 2011). This creates additional barrier to the penetration of heavy metals into the root (Liu et al. 2004, Probst et al. 2009). An increase in carboxyl groups was also revealed in the structure of the cell wall of the pine needles under conditions of aerotechnogenic pollution by nickel and copper (Galibina and Terebova 2008). Under salt stress in glycophyte Oryza sativa, it is also assumed that the carboxyl groups of polysaccharides of leaf cell wall are involved in the reduction of the toxic effect of $\mathrm{NaCl}$ (Aguino et. 2011). The amount of phenolic compounds in the leaf cell wall of $T$. maritima and $P$. maritima increases with increasing salinity of sea water from $0 \%$ to $20 \%$, while the protein content decreases (Table 5). For both studied plant species no correlation was registered between salinity and number of cell wall groups in the root of the plants.

The synthesis of phenolic compounds in plants is known to increase by stress ex- posure (Isah 2019). Thus, with annual $\mathrm{CO}_{2}$ exposure, an increase in the content of phenolic compounds (caffeic acid in leaf; p-coumaric acid and verbascoside in root) in P. maritima was obtained in a laboratory experiment (Davey et al. 2004). The adaptive role of phenols in plant metabolism is well-established, especially in defense mechanisms (Lavid et al. 2001). Most phenolic compounds have powerful antioxidant properties, neutralizing the effects of oxidative stress, some of them show the ability to chelate heavy metal ions. Phenylpropanoids are the basic molecules for the synthesis of lignin and suberin, strengthening the cell walls of plants (Kulbat et. 2016). Thus, the phenolic and pectin substances of the cell wall of halophytic species $P$. maritima and T. maritima participate in the binding mechanisms of salts and metals, phenolic substances provide tissue lignification, protect plants from the negative effects of salts on the White Sea littoral.

In addition to direct binding of elements, plant cell walls are involved in water exchange of plants (Gorshkova 2007), which is significantly disturbed by the action of salts and metals (Hall 2002, Yadav 2010, Laghlimi et al. 2015). In fact, under the conditions of salinity of soils and sea water, halophytes in the littoral zone are exposed to physiological drought (Touchette 2006). In our study, we showed high values of the swelling coefficient of the cell wall of coastal halophytes growing in water, especially for the leaves in comparison with terrestrial plants (Table 6). High $\mathrm{K}_{\mathrm{cw}}$ of cell wall were also established depending on the $\mathrm{pH}$ in the leaves of T. maritima and P. maritima (in average $1-14 \mathrm{~g}$ $\mathrm{H}_{2} \mathrm{O} \mathrm{g}^{-1}$ dry cell weight) and in the roots (1-6 $\mathrm{g} \mathrm{H}_{2} \mathrm{O} \mathrm{g}^{-1}$ dry cell weight), but 2 times lower than the leaves. According to the obtained results, cell wall swelling is minimal in the acidic range (Fig. 4). That means that cell walls contract or decrease in volume with decreasing $\mathrm{pH}$ in the apoplast or in the external environment. 
The swelling of the cell wall of the root increased with an increase in the salinity of sea water up to $20 \%$, especially in $P$. maritima. It is suggested that the higher the $\mathrm{K}_{\mathrm{cw}}$ of the cell wall in water is, the higher is its elasticity as well as generally higher hydraulic conductivity of the plant apoplast system (Meychik et al. 2010). The elasticity of halophyte tissue might be related to the elasticity of the cell wall. It is possible to make a conclusion about the high tissue elasticity of halophytic plants on the White Sea littoral based on the obtained high values of the cell wall swelling of the studied halophytes, especially in the leaf. A number of resources provide overviews of the flexibility of plant tissues as important component of plant-water relations (e.g. Steudle et al. 1977, Joly and Zaerr 1987). In fact, plants with relatively flexible cell walls (high elasticity) can maintain adequate turgor during periods of tissue-water decline (Clifford et al. 1998). It was documented that elevated elasticity and comparatively low osmotic potential may work in concert to effectively maintain vital cellular water content. Tolerance for lower soil-water potentials in plants while minimizing cell dehydration and shrinkage may foster by the describing concept termed the «cell water conservation hypothesis». Therefore, according to Tou- chette (2014), the accumulation of solutes in marine and coastal plants, causing decreases in osmotic potential, play an important role in plant-water relations and likely works with higher elasticity to achieve favorable cell volumes. It is generally held that plants residing in marine systems have higher leaf tissue elasticity (Touchette 2014).

Thus, the studied halophytes of $P$. maritima and T. maritima grow on unsorted sandy soil of the estuaries of the River Keret and periodically flooding with seawater enriched with nutrients and contaminated with heavy metals. The both species accumulate $\mathrm{Fe}, \mathrm{Mn}, \mathrm{Ni}, \mathrm{Cu}, \mathrm{Zn}, \mathrm{Pb}$ from the environment by whole the plant: by roots $(50-70 \%)$ and aboveground organs (30-50\%). The high ion-exchange ability of the halophyte cell wall has been established. The cell walls of the leaves of P. maritima and T. maritima are characterized by higher elasticity and ion-exchange ability and are more functionally active than in the roots. In the structure of the leaf and root cell wall of studied plants, phenolic and pectin substances predominate. The cell wall of plants is involved in the processes of accumulation and transport of elements within the plant and regulation of the water potential of plants in estuarine territories.

\section{References}

Alimov, A. F. (2007): Theory of Ecosystem Functioning: Application to Estuarine Ecology. Abstracts of the Symposium ECSA42 "Estuarine Ecosystems: Structure, Function and Management", 16-22 September 2007. Svetlogorsk, Russia, 8-9 pp. (In Russian).

Anjum, N. A, Ahmad, I., Figueira, E., Duarte, A. C. and Pereira, E. (2013): Phenological development stages variation versus mercury tolerance, accumulation, and allocation in salt marsh macrophytes Triglochin maritima and Scirpus maritimus prevalent in Ria de Aveiro coastal lagoon (Portugal). Environmental Science and Pollution Research, 20: 3910-3922.

Aquino, R. S., Grativol, C. and Mourão, P. A. S. (2011): Rising from the Sea: Correlations between sulfated polysaccharides and salinity in plants. PLoS ONE, 6(4): e18862. https://doi. org/10.1371/journal.pone. 0018862

Batalov, A. A., Giniyatullin, R. Kh. and Kagarmanov, I. R. (1991): Salicaceae - their participation in the formation of vegetation cover in technogenic landscapes of the Southern Urals. In: Proceedings of the conference «Flora and vegetation of Siberia and the Far East» dedicated to memory of L. M. Cherepnin. Krasnoyarsk, 73-74 pp. (In Russian). 
Boestfleisch, C., Papenbrock, J. (2017): Changes in secondary metabolites in the halophytic putative crop species Crithmum maritimum L., Triglochin maritima L. and Halimione portulacoides (L.) Aellen as reaction to mild salinity. PLoS ONE, 12(4): e0176303. https://doi. org/10.1371/journal.pone.0176303

Bowes, G. G., Bowes, S. K., RAO, G. M. and Estavillo, J. B. (2002): Reiskind $\mathrm{C}_{4}$ mechanisms in aquatic angiosperms: comparisons with terrestrial $\mathrm{C}_{4}$ systems. Functional Plant Biology, 29: 379-392.

Breslina, I. P. (1980): Seaside meadows of the Kandalaksha Bay of the White Sea. In: Biological and floristic studies in connection with the protection of nature in the Arctic. Apatity, 132-143 pp. (In Russian).

Clifford, S. C, Arndt, S. K, Corlett, J. E, Joshi, S., Sankhla, N., Popp, M. and Jones, H. G. (1998): The role of solute accumulation, osmotic adjustment, and changes in cell wall elasticity in drought tolerance in Ziziphus mauritiana (Lamk.). Journal of Experimental Botany, 49: 967977.

Davey, M. P., Bryant, D. N., Cummins, I., Gates, P., Ashenden, T. W., Baxter, R. and EDWARDS, R. (2004): Effects of elevated $\mathrm{CO}_{2}$ on the vasculature and phenolic secondary metabolism of Plantago maritima. Phytochemistry, 65: 2197-2204.

Davis, A. J., Dale, N. M. and Ferreira, F. J. (2003): Pearl millet as an alternative feed ingredient in broiler diets. Journal of Applied Poultry Research, 12(2): 137-144.

Galibina, N. A., Terebova, E. N. (2008): Characterization of cell wall properties in needles from scotch pine trees of various vigor. Russian Journal of Plant Physiology, 55(3): 419-425.

Gamaley, U. V. (2004): Transport system of vascular plants. SPb, 424 p. (In Russian).

GorshKova, T. A. (2007): The plant cell wall as a dynamic system. Moscow, 429 p. (In Russian).

Gulyaeva, E. N., Morozova, K. V., Markovskaya, E. F., Nikolaeva, N. N. and Zapevalova, D. S. (2016): Anatomical and morphological features of leaves of dominant species on the Barents Sea coast. Proceedings of PetrSU, 155: 13-19. (In Russian).

HALL, J. L. (2002): Cellular mechanisms for heavy metal detoxification and tolerance. Journal of Experimental Botany, 53: 1-11.

Han, R.-M., Lefèvre I., Albacete, A., Pérez-Alfocea, F., Barba-Espín, G., Díaz-Vivancos, P., Quinet, M., Ruan, C.-J., Hernández, J.A., Cantero-Navarro, E. and Lutts, S. (2013): Antioxidant enzyme activities and hormonal status in response to $\mathrm{Cd}$ stress in the wetland halophyte Kosteletzkya virginica under saline conditions. Physiologia Plantarum, 147: 352368.

HAN, R.-M., LefÈVRE, I., RuAN, C.-J., QIN, P. and LutTS, S. (2012): NaCl differently interferes with $\mathrm{Cd}$ and $\mathrm{Zn}$ toxicities in the wetland halophyte species Kosteletzkya virginica (L.) Presl. Plant Growth Regulation, 68: 97-109.

Iiy ama, K., Lam, T. and Stone, B. (1994): Covalent cross-links in the cell wall. Plant Physiology, 104: 315-320.

Ilyin, G.V., Usygina, I. S. and Kasatkina, N. E. (2015): Geoecological state of seas in the environment in the Russian Arctic under the present technogenic stresses. Bulletin of the Kola Science Center of the Russian Academy of Sciences, 21: 82-93. (In Russian).

JOLY, R. J, ZAERR, J. B. (1987): Alteration of cell-wall water content and elasticity in Douglas-Fir during periods of water deficit. Plant Physiology, 83: 418-422.

KaUSCH, H. (1990): Biological processes in the estuarine environment. In: W. Michaelis (eds): Estuarine water quality management. Coastal and estuarine studies (Formerly lecture notes on coastal and estuarine studies), vol. 36. Springer, Berlin, Heidelberg. https://doi.org/10.1007/ 978-3-642-75413-5_52

Kosobryukhov, A. A., Markovskaya, E. F. (2016): Halophyte adaptation to the gradient of conditions at the intertidal zone of the White Sea Cost (with Triglochin maritima L. as an example). Global Media Journal, 14(27): 37-45.

Kosova, K., Vítamvas, P., Urban, M. O., PrašIl, I. T. and Renaut, J. (2018): Plant abiotic stress proteomics: the major factors determining alterations in cellular proteome. Frontiers in Plant Science, 9: 122. doi: 10.3389/fpls.2018.00122 
KRZeStowsKa, M. (2011): The cell wall in plant cell response to trace metals: Polysaccharide remodeling and its role in defense strategy. Acta Physiologiae Plantarum, 33: 35-51.

KulBAt, K. (2016): The role of phenolic compounds in plant resistance. Biotechnology and Food Science, 80(2): 97-108.

Laghlimi, M., Baghdad, B., El Hadi, H. and Bouabdli, A. (2015): Phytoremediation mechanisms of heavy metal contaminated soils: A review. Open Journal of Ecology, 5: 375388.

Lavid, N., Schwartz, A., Yar Den, O. and Tel-Or, E. (2001): The involvement of polyphenols and peroxidase acitivities in heavy metal accumulation by epidermal glands of water lily (Nymphaeceaea). Planta, 212(3): 323-331.

LiU, H. Y., LiAO, B. H. and Lu, S. Q. (2004): Toxicity of surfactant, acid rain and $\mathrm{Cd}^{2+}$ combined pollution to the nucleus of Vicia faba root tip cells. Chinese Journal of Applied Ecology, 15: 493-496.

Lokhande, V. H., Srivastava, S., Patade, V. Y., Dwivedi, S., Tripathi, R. D., Nikam, T. D. and SupRASANNA, P. (2011): Investigation of arsenic accumulation and tolerance in Sesuvium portulacastrum (L.). Chemosphere, 82: 529-534.

MABERLY, S. C., MADSEN, T. V. (2002): Freshwater angiosperm carbon concentrating mechanisms: processes and patterns. Functional Plant Biology, 29: 393-405.

MANOUSAKI, E., KALOGERAKIS, N. (2011): Halophytes - an emerging trend in phytoremediation. International Journal of Phytoremediation, 13: 959-969.

Manousaki, T., Hull, P. M., Kushe, H., Machado-Schaffino, G., Franchini, P., Harrod, C., Elmer, K. R. and Meyer, A. (2013): Parsing parallel evolution ecological divergence and differential gene expression in the adaptive radiations of thick-lipped midas cichlid fishes from Nicaragua. Molecular Ecology, 22: 650-669.

Markovskaya, E. F., Gulyaeva, E. N. (2020): Role of stomata in adaptation of Plantago maritima L. Plants to tidal dynamics on the White Sea coast. Russian Journal of Plant Physiology, 67(1): 68-75.

MeychiK, N. R., Nikolaeva, Yu. I. and Yermakov, I. P. (2006): Ion-exchange properties of cell walls of Spinacia oleracea L. roots under different environmental salt conditions. Biochemistry (Moscow), 71: 781-789.

MeychiK, N. R. (2007): Ion-exchange properties and diffusion in cell walls of plants. Moscow, 48 p. (In Russian).

MeychiK, N. R., Yermakov, I. P. (1999): A new approach to the investigation on the tonogenic groups of root cell wall. Plant Soil, 217: 257-264.

Meychik, N. R., Yermakov, I. P., Khonarmand, S. D. and Nikolaeva, Y. I. (2010): Ionexchange properties of cell walls in Chickpea cultivars with different sensitivities to salinity. Russian Journal of Plant Physiology, 57: 620-630.

Milić, D., Luković, J., Ninkov, J., Zeremski-Škorić, T., Zorić, L., Vasin, J. and Milić, S. (2012): Heavy metal content in halophytic plants from inland and maritime saline areas. Central European Journal of Biology, 7(2): 307-317.

NoviKov, M. A. (2017): On the background values of heavy metal content in bottom sediments of the Barents Sea. Bulletin of the Murmansk State Technical University, 20(1/2): 280-288. (In Russian).

Oreshnikova, N. V., Krasilnikov, P. V. and Shoba, S. A. (2012): Marsh soils of the Karelian shore of the White Sea. Moscow University Soil Science Bulletin, 67(4): 152-158.

Pandey, A., Rajamani, U., Verma, J., Subba, P., Chakraborty, N. and Datta, A. (2010): Identification of extracellular matrix proteins of rice (Oryza sativa L.) involved in dehydrationresponsive network: A proteomic approach. Journal of Proteome Research, 9: 3443-3464. doi: $10.1021 / \mathrm{pr} 901098 \mathrm{p}$

Parrotta, L., Guerriero, G., CAi, G. and Hausman, J-F. (2015): Target or barrier? The cell wall of early- and later-diverging plants vs cadmium toxicity: Differences in the response mechanisms. Frontiers in Plant Science, 6: 133.

Pelloux, J., Rusterucci, C. and Mellerowicz, E. J. (2007): New insights into pectin methylesterase structure and function. Trends in Plant Science, 12: 267-277. 
Pendias, A. (2010): Trace Elements in Soils and Plants. $4^{\text {th }}$ edition. Boca Raton, FL, USA: CRC Press/Taylor \& Francis Group, 548 p.

Polynov, B. B. (1956): Essay on the development of soil theory as a branch of natural science. Moscow, 659-726 pp. (In Russian).

Probst, A., Liu, H., Fanjul, M., LiaO, B. and Hollande, E. (2009): Response of Vicia faba L. to metal toxicity on mine tailing substrate: Geochemical and morphological changes in leaf and root. Environmental and Experimental Botany, 66: 297-308.

PULFORD, I. D., WATSON, C. (2003): Phytoremediation of heavy metal-contaminated land by trees - a review. Environment International, 29: 529-540.

REBOREDA, R., CAÇADOR, I. (2007): Halophyte vegetation influences in salt marsh retention capacity for heavy metals. Environmental Pollution, 146: 147-154.

Richter, J., Ploderer, M., Mongelard, G., Gutierrez, L. and Hauser, M-T. (2017): Role of CrRLK1L Cell Wall Sensors HERCULES1 and 2, THESEUS1, and FERONIA in Growth Adaptation Triggered by Heavy Metals and Trace Elements. Frontiers in Plant Science, 8: 1554. doi: 10.3389 /fpls.2017.01554

SeKmen, A. H., TURKan, I. and TAKIO, S. (2007): Differential responses of antioxidative enzymes and lipid peroxidation to salt stress in salt-tolerant Plantago maritima and salt-sensitive Plantago media. Physiologia Plantarum, 131: 399-411.

SELMAR, D., KLEINWÄCHTER, M. (2013): Influencing the product quality by deliberately applying drought stress during the cultivation of medicinal plants. Industrial Crops and Products, 42: 558-566.

Sergienko, L. A., DyachKova, T. Y. and Androsova, V. I. (2017) Habitat characterization and population structure of Triglochin maritima L. (Juncaginaceae) in the tidal zone of the White Sea littoral. Proceedings of PetrSU, 163: 57-63. (In Russian).

Shannon, M., GRIEVE C. (1998): Tolerance of vegetable crops to salinity. Scientia Horticulturae, 78: 5-38.

Sharova, E. N. (2004): The plant cell wall. SPb, 156 p. (In Russian).

Steudle, E., Zimmerman, U. and LutTGe, U. (1977): Effect of turgor pressure and cell size on the wall elasticity of plant cells. Plant Physiology, 59: 285-289.

Stoltz, E., Greger, M. (2002): Accumulation properties of $\mathrm{As}, \mathrm{Cd}, \mathrm{Cu}, \mathrm{Pb}$ and $\mathrm{Zn}$ by four wetland plant species growing on submerged mine tailings. Environmental and Experimental Botany, 47: 271-280.

Telesh, I. V., Khlebovich, V. V. (2010): Principal processes within the estuarine salinity gradient: A review. Marine Pollution Bulletin, 61: 149-155.

Terebova, E. N., Markovskaya, E. F., Androsova, V. I., Galibina, N. A. and Kaipiainen, E. (2017): Potential for Salix schwerinii E. Wolf to uptake heavy metals in the contaminated territories of mining industry in the north-west Russia. Siberian Journal of Forest Science, 1: 74-86.

Terebova, E. N., Markovskaya, E. F. and Shmakova, N. Yu. (2018): Ion-exchange properties and swelling capacity of leaf cell wall of Arctic plants. Czech Polar Repots, 8(1): 132-142.

Titov, A. F., Talanova, V. V. and Kaznina, N. M. (2011): The physiological basis of plant resistance to heavy metals. In: L.V Vetchinnikova (eds.): The physiological basis of plant resistance to heavy metals. Petrozavodsk, 77 p. (In Russian).

Toderich, K. N., Goldshtein, R. I., Aparin, V. B., IDZikowsKa, K. and Rashidova, G. S. (2001): Environmental state and analysis of phytogenetic resources of halophytic plants for rehabilitation and livestock feeding in arid sandy deserts of Uzbekistan. In: S.-W. Breckle, W. Weste, W. Wucherer (eds.): Sustainable Land use in Deserts. Springer, Berlin Heidelberg, New York, 154-165 pp.

Touchette, B. W. (2006): Salt tolerance in a Juncus roemerianus brackish marsh: spacial variations in plant water relations. Journal of Experimental Marine Biology and Ecology, 337: $1-12$.

Touchette, B. W., Marcus, S. E. and Adams, E. C. (2014): Bulk elastic moduli and solute potentials in leaves of freshwater, coastal and marine hydrophytes. Are marine plants more rigid? AoB PLANTS, 6: plu014; doi:10.1093/aobpla/plu014 
Van Osten, M. J., MagGio, A. (2015): Functional biology of halophytes in the phytoremediation of heavy metal contaminated soils. Environmental and Experimental Botany, 111: 135-146.

Vandecasteele, B., Meers, E., Vervaeke, P., De Vos, B., Quataert, P. and Tack, F. M. G. (2004): Growth and trace metal accumulation of two Salix clones on sediment-derived soils with increasing contamination levels. Chemosphere, 58: 995-1002.

Veselkin, D. V., Markovskaya, E. F., Betekhtina, A. A., Sonina, A. V. and Sergienko, L. A. (2016): Mycorrhizal formation in vascular plants of the white sea western coas. Proceedings of PetrSU, 161: 20-26. (In Russian).

Vinogradov, A. P. (1957): Geochemistry of rare and scattered chemical elements in soils. Geochemistry of rare and scattered chemical elements in soils. Moscow, 238 p. (In Russian).

Vorobeva, L. A. (2006): Theory and practice of chemical analysis of soils. GEOS Publishers, Moscow, 400 p. (In Russian).

YADAV, S. K. (2010): Heavy metals toxicity in plants: An overview on the role of glutathione and phytochelatins in heavy metal stress tolerance of plants. South African Journal of Botany, 76: 167-179.

Zagorchev, L., KAmenova, P. and OdjaKova, M. (2014): The role of plant cell wall proteins in response to salt stress. Hindawi publishing corporation The Scientific World Journal, Volume 2014, Article ID 764089, 9 pages. http://dx.doi.org/10.1155/2014/764089

Zhivotovsky, O. P., Kuzovkina, J. A., Schulthess, C.-P., Morris, T., Prttinelli, D. and Ge, M. (2011): Hydroponic screening of willows (Salix L.) for lead tolerance and accumulation. International Journal of Phytoremediation, 13: 75-94.

\section{Web sources / Other sources}

[1] Order of Ministry of Agriculture of the Russian Federation of Decemder 13. 2016. №. 552. (2016). On the approval of water quality standards for water bodies of fishery value, including the standards of maximum permissible concentrations of harmful substances in the waters of water bodies of fishery value. (In Russian).

[2] State Report on the State of the Evironment of the Republic of Karelia in 2017 (2018). In: A.N. Gromtsev (eds.), Petrozavodsk, 292 p. (In Russian). 